NBER WORKING PAPER SERIES

THE DEFICIT GAMBLE

\author{
Laurence Ball \\ Douglas W. Elmendorf \\ N. Gregory Mankiw
}

Working Paper No. 5015

\author{
NATIONAL BUREAU OF ECONOMIC RESEARCH \\ 1050 Massachusetts Avenue \\ Cambridge, MA 02138 \\ February 1995
}

We are grateful to Derek Briggs for research assistance, to Stephen Cecchetti for providing data, to Patrick Kehoe for comments on an early draft, and to the National Science Foundation for financial support. This paper is part of NBER's research program in Economic Fluctuations. Any opinions expressed are those of the authors and not those of the Congressional Budget Office or the National Bureau of Economic Research.

(C) 1995 by Laurence Ball, Douglas W. Elmendorf, and N. Gregory Mankiw. All rights reserved. Short sections of text, not to exceed two paragraphs, may be quoted without explicit permission provided that full credit, including $\odot$ notice, is given to the source. 


\title{
THE DEFICIT GAMBLE
}

\begin{abstract}
The historical behavior of interest rates and growth rates in U.S. data suggests that the government can, with a high probability, run temporary budget deficits and then roll over the resulting government debt forever. The purpose of this paper is to document this finding and to examine its implications. Using a standard overlapping-generations model of capital accumulation, we show that whenever a perpetual rollover of debt succeeds, policy can make every generation better off. This conclusion does not imply that deficits are good policy, for an attempt to roll over debt forever might fail. But the adverse effects of deficits, rather than being inevitable, occur with only a small probability.
\end{abstract}

Laurence Ball

Department of Economics Johns Hopkins University 3400 N. Charles Street

Baltimore, MD 21218 and NBER
N. Gregory Mankiw Department of Economics 223 Littauer Center Harvard University Cambridge, MA 02138 and NBER

Douglas W. Elmendorf

U.S. Congress

Congressional Budget Office

Macroeconomic Analysis Division

405 House Annex 2

Washington, DC 20515 


\section{Introduction}

The conventional wisdom holds that government budget deficits crowd out capital, reduce national income, and lead to lower living standards for future generations. Indeed, this is the standard critique of U.S. fiscal policy in the 1980s. According to this view, future historians looking back at the 1980 s will see a generation enjoying prosperity at the expense of their children and grandchildren.

This paper argues that a less prosperous future is only one possible consequence of a period of large budget deficits. Indeed, the probability of this outcome is low. With a much higher probability, temporarily profligate fiscal policy can raise the entire path of consumption above what it otherwise would have been. Future historians looking back at the fiscal policy of the $1980 \mathrm{~s}$ may well see it as leading to a period of greater prosperity without any adverse long-run consequences.

More generally, we propose a new view of budget deficits. This view emphasizes the uncertainty about the future of the economy--in particular, the future of economic growth and of asset returns. In an uncertain world, deficits do not lead inexorably to future hardship. Instead, a deficit is a gamble. It is an imprudent policy, because it imposes a significant burden on future generations in some realizations of history. But in most possible outcomes, the future effects of deficits are benign.

our starting point in reaching these conclusions is the 
observation that the average return on government debt is below the average growth rate of the economy. The government can, therefore, most likely get away without paying for a period of budget deficits. After running a deficit for a while, it can forever roll over the debt and accumulated interest. Because the economy's income will likely grow faster than the debt will accumulate, the debt-income ratio will fall over time. In other words, a country with a large public debt can most likely grow itself out of its problem.

We document the probable success of such a policy in section II. We call the policy a Ponzi gamble because it is an attempt at a Ponzi scheme--a perpetual rollover of debt--that is not certain to succeed. We consider a Ponzi gamble that starts with a debtincome ratio similar to the ratio in the U.S. today. If future economic growth turns out to be low relative to the return on government debt, the gamble will produce a rising debt-income ratio. In this case, the government will eventually be forced to raise taxes. But, using historical data on growth rates and interest rates, we estimate that the probability of this outcome is only about ten or twenty percent. With a probability of eighty or ninety percent, a debt of the size inherited from the 1980 s will never force the government to raise taxes higher than they otherwise would have been.

In section III we begin to examine the implications of Ponzi gambles for economic welfare. The framework we adopt is the standard overlapping-generations model of economic growth. In this 
model, there is a simple relationship between the success and desirability of a Ponzi gamble. If the path of history would allow a Ponzi gamble for government debt to succeed, then along that path it is possible to reallocate resources in a way that raises the welfare of all generations as of the time of their birth. This reallocation begins with current generations consuming more and investing less than they otherwise would have. The results in Sections II and III together suggest a powerful conclusion: in the United states, a policy involving budget deficits will likely end up producing a Pareto improvement.

But don't budget deficits crowd out capital? How can a successful Ponzi gamble be harmless for future generations despite this effect? We take up these questions in section IV. One logical possibility is that the economy is dynamically inefficient-that is, it has accumulated more capital than the Golden Rule level. It is well known that, in dynamically inefficient economies, Ponzi schemes can succeed with certainty. In this case, government debt raises welfare because crowding out is desirable. We view this interpretation as the wrong one, however, for the U.S. economy appears to satisfy a sufficient condition for dynamic efficiency.

We interpret the evidence as suggesting that the U.S. economy is dynamically efficient and that Ponzi gambles are likely but not certain to succeed. We present two examples of economies with these properties. In the first example, government debt reduces expected consumption but raises welfare in most realizations of 
history, because it substitutes riskless debt for risky capital and thereby reduces the uncertainty that consumers face. In the second example, a Ponzi gamble raises consumption in most realizations of history because the existence of safe government debt encourages households to invest in capital with higher risk and higher return. In both examples, the government Ponzi gamble is undesirable for some generations in some realizations of history, but it is desirable for all generations in most realizations of history.

We offer our conclusions in section $v$. In the end, the analysis of this paper is not a defense of budget deficits. A Ponzi gamble may fail, and then the government must raise taxes on future generations. Moreover, this tax increase is especially undesirable, for it occurs in those realizations of history in which future generations are already burdened by low economic growth. The risk of this adverse outcome, rather than any inevitable burden, is the true cost of budget deficits.

\section{The Likelihood of successful Ponzi Gambles}

Since 1980 the U.S. federal government has run budget deficits and increased the government debt to about one-half of national income. Suppose that the government now decides to balance the primary budget, so that taxes equal non-interest spending. ${ }^{1}$ what

1 This supposition has some basis in fact: the congressional Budget office currently projects a small primary surplus in the federal budget for fiscal years 1995 through 2002 (CBO, 1994). In recent years, Italy, Greece, and Ireland have also eliminated their primary deficits after running up large debts. 
is the probability that the government can avoid raising taxes to pay off any of the debt and accumulating interest? In other words, what is the probability that the government can pull off this Ponzi gamble?

Clearly, the answer depends on the statistical properties of the economy's growth rate and the return on government debt. In this section we examine the historical data on these two variables. our goal is to obtain a rough estimate of the probability that a Ponzi gamble for government debt will succeed. Our calculations are similar in spirit to the ones reported by Bohn (1991). ${ }^{2}$

\section{Historical Patterns}

If the government's primary budget is balanced, the debtincome ratio grows by $(1+r) /(1+g)$, where $r$ is the interest rate and $g$ is the growth rate of income. Therefore, to evaluate the likelihood of a successful ponzi gamble, we examine the historical behavior of $(1+r) /(1+g)$. All our data are annual and, for simplicity, in nominal terms. (Note that $(1+r) /(1+g)$ is unaffected by whether $r$ and $g$ are measured in nominal or real terms.) The Appendix describes the data sources.

We consider three alternative measures of the rate of return on government debt. The first rate, denoted $r^{\wedge}$, is the yield on

2 Bohn (1991) finds that a Ponzi gamble fails with a probability less than .001, which is much lower than our estimates. The source of this difference may be that Bohn assumes a fixed interest rate on debt, whereas we treat the interest rate as stochastic. 
U.S. government bonds with one year to maturity. If the budget deficit were financed entirely through one-year bonds, the debt would grow at rate $\mathrm{r}^{\mathrm{A}}$.

The second rate of return, $r^{8}$, is total interest payments in a year divided by the par value of outstanding debt at the beginning of the year. This measure captures the maturity mix that makes up the actual U.S. government debt. If the government were to finance the debt with the same mix of instruments used historically, the par value of the debt would grow at rate $\mathbf{r}^{\mathrm{B}}$.

The third rate of return, $r^{c}$, is the sum of total interest payments and the revaluation of outstanding debt, divided by the market value of debt at the beginning of the year. This measure, in contrast to $r^{B}$, includes the revaluation of outstanding debt in response to changes in interest rates. If the government were to finance deficits with the historical mix of instruments, the market value of the debt would grow at rate $r^{c}$. This data series is arguably the most appropriate for our question. It has the disadvantage, however, of being available for a shorter period of time than the previous two series.

Table 1 presents some summary statistics. We can see the differences among the three rates of return by considering the period between 1920 and 1992--the longest range for which all series are available. The average return including revaluations $\mathbf{r}^{\mathrm{c}}$ exceeds the average yield on government debt $r^{B}$ by about 50 basis points. The average yield exceeds the yield on one-year bonds $r^{A}$ by about 60 basis points. Thus, the results below will depend to 
some extent on which series is used.

The danger in a government Ponzi gamble is that the debtincome ratio will grow so large that taxes must be raised. In this case, the Ponzi gamble will have failed. If the primary budget is balanced, the debt-income ratio reaches the critical level only if $(1+r) /(1+g)$ is sufficiently larger than one for sufficiently many years. Table 1 shows that $(1+r) /(1+g)$ has averaged less than one historically, ranging from 0.981 to 0.995 depending on the time period and interest rate. Since this is less than one, Ponzi gambles do succeed "on average."

To decide how likely success is, we must take uncertainty into account. The standard deviation of $(1+r) /(1+g)$ is roughly 0.09 for the longer samples, but is only half as large for the postwar sample when $\mathrm{g}$ is less volatile. Table 1 also shows the fraction of historical periods of different lengths for which $(1+r) /(1+g)$ was greater than one. For decade-long periods, this fraction is about one-third for the longest sample and about one-sixth for the postwar sample. Thus, over most long periods, the growth of the economy has exceeded the return on government debt.

Table 1 suggests that the probability of success of a Ponzi gamble depends somewhat on the historical period used as a reference. Since 1946, both the level and volatility of $(1+r) /(1+g)$ have been lower than they were earlier. If these conditions persist, the outlook for a Ponzi gamble is substantially brighter than if $(1+r) /(1+g)$ returns to its prewar behavior. Below we report results both for the longer samples and for the postwar 
sample.

\section{Time-Series Processes}

Here we characterize the dynamic behavior of $(1+r) /(1+g)$ in order to estimate the probability that a Ponzi gamble for government debt will fail. For simplicity, we model the univariate process for $(1+r) /(1+g)$ rather than modeling $r$ and $g$ separately. Also, we focus on the logarithm of $(1+r) /(1+g)$, since the innovation of the logarithm more naturally fits the standard assumption of a normal distribution. (We experimented with estimating the process in the level rather than the log, and the results were almost identical to those presented below.) For ease of interpretation, note that the first-order Taylor approximation to $\log [(1+r) /(1+g)]$ is simply $r-g$.

We found that $\log [(1+r) /(1+g)]$ is well described by a firstorder autoregressive process. Estimates are presented in Table 2 . For $r^{A}$ and $r^{B}$, the first-lagged value (and a constant) explain between 20 and 35 percent of the variation over the longer sample, and between 10 and 25 percent of the variation in the postwar sample. The adjusted $\mathrm{R}^{2}$ statistics for the $\mathrm{r}^{\mathrm{C}}$ specifications are noticeably smaller, because much of the variation in this series is driven by (unpredictable) revaluations of outstanding bonds.

The estimated autoregressive coefficients range between 0.21 and 0.59 , with the smaller values occurring in the postwar sample. As one would expect, Dickey-Fuller tests always reject the null hypothesis of a unit root in this series. In all cases, adding a 
second autoregressive term has little effect on the results. Furthermore, standard diagnostic tests applied to the residuals show no significant serial correlation, indicating that a stationary AR(1) process accounts fairly well for the basic dynamics of $(1+r) /(1+g)$.

There is some evidence that the residuals from these processes are not normally distributed. First, the residuals are generally positively skewed, suggesting that large shocks are more likely to be positive than negative. Also, the residuals are significantly leptokurtotic, implying that large shocks of either sign are more likely than if they were drawn from a normal distribution with the same variance. In our simulations below, we use bootstrap techniques to mimic these higher moments. In practice, however, these features of the data are not important for our purposes. simulations assuming normal errors yield similar results to those reported below with the bootstrapped errors.

\section{Simulations}

We can now estimate the probability that a Ponzi gamble for government debt will fail. These estimates involve three components: the initial debt-income ratio, the debt-income ratio at which the gamble fails, and simulations of the possible future paths of $(1+r) /(1+g)$. We assume that the government balances its primary budget, so that the path of the debt-income ratio depends only on $(1+r) /(1+g)$.

The current debt-income ratio in the United states is roughly 
0.5 , which we use as the starting point for the simulations. It is less clear how large this ratio can become before the Ponzi gamble fails. In standard models of the sort considered below, the constraint on the size of the debt is the level of private wealth: the government cannot roll over an amount of debt that exceeds the total demand for assets. In practice, however, it is unlikely that the government would allow the debt to reach that level. At some lower level, the debt would generate sufficient concern to compel a tax increase to reduce it. Nonetheless, the bound on the debt appears to be considerably higher than the current U.S. level. The market value of the U.S. debt reached $115 \%$ of GNP in 1945 . Currently, the debt-income ratio is 1.32 in Belgium and 1.13 in Italy; these governments do not appear on the verge of default, although they have shifted to primary budget surpluses. In light of these cases, we consider 1.0 and 1.5 as possible bounds on the debt-income ratio.

We simulate future values of the debt-income ratio using simulations of $\log [(1+r) /(1+g)]$ derived from the equations estimated above. To start, imagine that all future shocks to the time-series process were identically zero. In this case, $\log [(1+r) /(1+g)]$ would asymptote to its average value. Because this value is less than one, the debt-income ratio would fall exponentially over time. For example, for a simulation based on the first equation in Table 2 , the debt-income ratio would be 0.3 in 25 years, 0.2 in 50 years, 0.1 in 100 years, and 0.0003 in 500 years. Under this scenario, the government's Ponzi gamble would 
succeed with certainty.

of course, in the actual economy, there are shocks to $\log [(1+r) /(1+g)]$. These shocks creates a strictly positive probability that the debt-income ratio will exceed any given critical value at some point in the future. To quantify this probability, we generate 5000 Monte carlo simulations of each of the time-series processes in Table 2. In each simulation, we draw a set of random shocks for the next 1000 years from a distribution based on the historical experience using bootstrap techniques. We then calculate the evolving debt-income ratio over that period. For each time-series process, we use the set of simulations to calculate the probability that the Ponzi gamble fails by a certain date.

Table 3 presents the estimated probabilities of failure of the Ponzi gamble for each time-series process. In the top panel of the table, the critical level of the debt-income ratio is assumed to be $1.0 ;$ in the bottom panel, the critical level is assumed to be 1.5 . In each case, we report the probability of failure within periods of various lengths, as well as the probability as the period goes to infinity (which is well approximated by the probability within 1000 years). For estimates using either of the longer samples, the probability that the debt-income ratio ever reaches 1.0 is generally about 0.2 , and the probability that the ratio reaches 1.5 is about 0.1. For estimates based on the postwar sample, the probability of hitting either critical value is only slightly above zero. 
In fact, the United states has already run a successful Ponzi gamble during the postwar period. After increasing sharply during the Depression and the Second World War, the U.S. debt-income ratio fell fairly steadily over the next thirty years. Part of this decline can be attributed to a net primary budget surplus during this period, but most of the decline occurred because $(1+r) /(1+g)$ averaged less than one. Specifically, if the government had balanced its primary budget between 1945 and 1975, the debt-income ratio would have declined from 115 percent to 39 percent. Because of the net primary surplus, the ratio actually declined somewhat more, to 27 percent.

To sum up: the historical data on growth rates and rates of return give a sanguine view about the possibility of the U.S. government running a successful Ponzi gamble. If the debt-income ratio begins at one-half (roughly its current level) and can rise as high as one (which it has done in the past), the government most likely will never need to raise taxes to pay off the debt. With a high probability, the government can grow itself out of its debt problem simply by balancing the primary budget in the future.

\section{Caveats and Extensions}

The calculations above suggest that a Ponzi gamble succeeds with a high probability. We view these estimates as suggestive rather than definitive. Here we discuss briefly several potentially relevant issues that these estimates do not take into account. 
First, our estimates of the probability of a successful Ponzi gamble assume that debt has no effect on interest rates. One might expect that a high debt-income ratio would raise the government's cost of borrowing and increase the probability that a deteriorating Ponzi gamble would fail. Yet, when we tried including the debtincome ratio as an explanatory variable for $(1+r) /(1+g)$, we did not find a positive effect. As an empirical matter, ignoring the effect of debt on interest rates does not appear problematic.

Second, we have not incorporated uncertainty about government spending. If the United states became involved in a major war, for example, it would be necessary to increase government spending significantly, but it might not be desirable to raise taxes by the same amount. If the primary budget had been balanced before the war, the increased budget deficit would raise the debt-income ratio and might cause the Ponzi gamble to fail. Our estimates make no allowance for this possibility: they take account of uncertainty only in growth rates and asset returns. Future work might model government spending as an additional source of uncertainty.

A third issue that we have not addressed is the potential effect of fiscal policy on the size of the tax base. Our discussion of Ponzi gambles assumes implicitly that balancing the primary budget is no more difficult after an accumulation of debt than it is before. It is unclear whether this assumption is valid, however. In general, government debt has two opposing effects on the tax base: debt increases the base directly because interest payments are taxable income, and debt decreases the base by 
reducing the capital stock and thereby income. In the second illustrative economy analyzed in section IV, these effects are exactly offsetting (in all states of the world), and there is no change in the tax base. More generally, it is not clear whether this consideration raises or lowers the probability that a Ponzi gamble will fail. Again, we leave this question for future research.

\section{Can Deficits Raise Welfare?}

The calculations in the previous section suggest that a Ponzi gamble is likely to succeed in an economy like the United states. The government can finance expenditures by issuing debt, and probably never have to raise taxes to retire the debt. In this section and the next, we investigate the welfare effects of such a policy. If the government can make transfers to some individuals without raising anyone's taxes, can it engineer a Pareto improvement? We ask this question in a conventional model of an economy with overlapping generations.

In a deterministic economy, the feasibility of a Ponzi scheme does imply that Pareto-improving government interventions exist (see O'Connell and Zeldes, 1988). This section derives an analogous result for stochastic economies. We show there exists a debt policy that yields a Pareto improvement in all realizations of history in which a Ponzi gamble succeeds. That is, all generations are better off as long as the government can continue to roll over its debt. We also show that some generations suffer if a Ponzi 
gamble fails, forcing a tax increase. But if the probability of failure is small--as suggested by the simulations in the previous section--then debt produces a Pareto improvement with a high probability.

After deriving our main welfare results in this Section, in Section IV we explore the channels through which debt can raise welfare. A Ponzi gamble, even if successful, reduces the accumulation of physical capital, because savers hold government bonds instead. How can debt raise welfare despite this crowdingout effect? One possible answer is that the economy is dynamically inefficient--that crowding-out is desirable because the economy has accumulated too much capital. We do not view this explanation as plausible, however: as discussed below, modern economies appear to be dynamically efficient. section IV therefore focuses on channels through which debt can raise welfare even under dynamic efficiency $\cdot^{3}$

The Model

Our model is essentially the Diamond (1965) model with the addition of uncertainty. An individual lives for two periods, and

3 The questions addressed in sections III and IV are related to those addressed by Bohn (1993). Bohn also considers the effects of debt rollover in stochastic economies with low safe interest rates. Instead of using an overlapping-generations model with capital accumulation, however, Bohn examines a Lucas endowment economy with two kinds of consumers--one infinitely lived and one that lives only a single period. Despite the differences in structure, the models have some broad similarities. In both models, deficits impose risks on future taxpayers ex ante, even though adverse effects are not inevitable ex post. 
the population is constant. An individual supplies one unit of labor when young and receives a wage. He may also receive a lumpsum transfer, which the government finances by issuing one-period bonds. Transfers can be negative (there can be taxes), in which case the government retires bonds. A young individual divides his income after transfers between current consumption and savings. He uses his savings to purchase one or more kinds of physical capital and to buy government bonds (if any exist). When old, the individual consumes the gross return on his savings, again net of any transfers. An individual born in period $t$ chooses $h i s$ total savings and the composition of his assets to maximize

(1) $\quad u\left(c_{t}^{y}\right)+E_{t} v\left(c_{t+1}^{o}\right)$,

where $c_{t}^{y}$ is the consumption of a young person at $t, c_{t+1}^{0}$ is the consumption of an old person at $t+1, E_{t}$ is the expectation at time $t$, and $u(\cdot)$ and $v(\cdot)$ are strictly concave.

For simplicity, we assume that capital is productive for one period and then depreciates fully. Thus, the per-capita capital stock in period $t, k_{1}$, equals per-capita investment in period $t-1$. When we allow for more than one kind of capital, $k_{t}$ is a vector. Per-capita output in period $t$ is $f\left(k_{1}, \theta_{t}\right)$, where $\theta$ is the state of nature and $f(\cdot)$ is concave in $k$. Factor markets are competitive, so the gross return on capital is $\partial f / \partial k$ and the wage equals $f(k)-$ $k(\partial f / \partial k)$. The return on government bonds is determined by the equilibrium of supply and demand. The supply of bonds in any period equals transfers plus the gross return on existing bonds, 
which the government rolls over. The demand for bonds comes from the optimization problem of the young.

The state of nature $\theta$ is random. We denote a particular sequence of states for periods $t=0,1,2, \ldots$ by $\left\{\theta_{\imath}\right\}$ and call it a "realization of history." Because of the uncertainty about $\theta$, the return on capital, $\partial f / \partial k$, is stochastic. The return on capital, therefore, is not the same as the return on government debt.

\section{Dynamic Efficiency}

our model and many of our results are quite general. The average growth rate of the economy can be either greater or less than the interest rate on government debt, and the economy can be either dynamically efficient or dynamically inefficient. In some of our analysis, however, we focus on the case of dynamic efficiency. Our definition of this concept follows Peled (1982) and Abel, Mankiw, Summers, and Zeckhauser (1989):

Definition: An allocation of resources is dynamically efficient if it is impossible to reallocate resources in a way that raises utility in equation (1) for some generation $t$ in some realization of history $\left\{\theta_{3}\right\}$, and does not reduce utility for any generation $t^{\prime}$ in any possible realization of history $\left\{\theta^{\prime}\right\}$.

That is, if we consider an agent to be a person born at a particular time and in a particular state of nature, then dynamic 
efficiency means there is no way to benefit one agent without hurting another.

Abel et al. derive a sufficient condition for dynamic efficiency in stochastic overlapping-generations economies: the "AZ" condition that the total return on capital exceeds investment in all periods and all states of nature. These authors also present empirical evidence that their condition holds in major developed countries. Motivated by these results, we will sometimes consider the implications of the AZ condition in our model.

While our definition of dynamic efficiency is common, it is not the only one. Cass (1972) and Blanchard and Weil (1992) use a weaker definition that requires efficiency in producing consumption goods but not an optimal allocation of consumption. We focus on our stronger version of dynamic efficiency because it appears to be satisfied in actual economies and because it yields stronger implications.

\section{Ponzi Schemes and Ponzi Gambles}

our goal is to determine the welfare effects of attempts to roll over government debt. The first step is to define exactly what policies we have in mind. One possible policy is a Ponzi scheme, defined as follows:

Definition: In a Ponzi scheme, the government issues a transfer to one generation when young and does not levy taxes on any generation in any state of nature. 
That is, a Ponzi scheme involves an initial deficit and then a certain, perpetual rollover of debt. Many previous authors have studied the properties of Ponzi schemes in both deterministic and stochastic models. We do not focus on such a policy, however, because it is likely to be infeasible: the government cannot roll over its debt in all realizations of history. (We return to this point below.)

Instead of Ponzi schemes, we focus on Ponzi gambles:

Definition: In a Ponzi gamble, the government issues a transfer to one generation when young. It does not levy taxes on any generation as long as $D<\lambda W$, where $D$ is the level of debt at the start of a period, $w$ is the wage of the young, and $\lambda$ is a positive constant. If this condition is ever violated, the government immediately retires the debt by levying taxes of $D$ on the young.

A Ponzi gamble is a Ponzi scheme with an escape clause: if the debt becomes too large, taxes are levied to retire it. The limit on the debt is proportional to the wage, which is the tax base when taxes are levied on the young. Thus a Ponzi gamble is similar in spirit to the policy considered in our empirical work, in which the bound on debt is proportional to income. In our analysis below, we assume that a Ponzi gamble is feasible for a sufficiently small choice of the bound $\lambda$. That is, we assume the government can carry out the policy in all states of nature if it sets a sufficiently 
conservative bound on the debt.4

When the government launches a Ponzi gamble, it may or may not end up levying taxes on future generations. We say that the gamble fails if taxes are raised (because debt reaches its upper bound), and the gamble succeeds if taxes are never raised.

\section{Pareto-Improving Interventions}

What are the welfare effects of a Ponzi gamble? When the government initiates the gamble by making a transfer, the effects on future generations are unclear, because taxes may or may not be raised. Our central result concerns realizations of history in which a Ponzi gamble succeeds, so taxes are not raised:

Proposition 1: starting from the decentralized equilibrium, there exists a reallocation of resources that raises utility for one generation and does not reduce utility for any generation in any realization of history in which a Ponzi gamble would succeed.

${ }^{4}$ Section IV presents two examples of economies in which Ponzi gambles are feasible for small $\lambda^{\prime} s$. In general, Ponzi gambles are feasible under mild restrictions on the model. A sufficient condition is that, in the no-intervention equilibrium, there exists an upper bound on $R_{1}$, the safe interest rate, and a positive lower bound on $W_{l} / W_{t-1}$, the change in the wage. If these bounds do not exist, then the ratio of the debt to the wage can grow by an arbitrarily large factor in a given period. In this case, the government can never issue safe debt. Even a tiny debt might grow so high in the next period that the government can neither roll it over nor raise sufficient taxes to pay it off. 
That is, if the government can run a successful Ponzi gamble, it can create a Pareto improvement. All generations benefit ex post-once the path of history is determined--even though, ex ante, a Ponzi gamble could have failed and the intervention could have hurt some generation. If a Ponzi gamble succeeds with a high probability, then the government can produce an ex-post improvement with a high probability.

Proposition 1 generalizes the result for deterministic models that the government can make all generations better of $f$ if it can run a Ponzi scheme. In the deterministic case, a feasible Ponzi scheme succeeds with certainty, so all generations gain with certainty. Yet, this result is relevant only to dynamically inefficient economies, in which Ponzi schemes are feasible. Proposition 1, by contrast, holds even under dynamic efficiency. To establish Proposition 1, we first present a lemma:

Lemma: In any realization of history in which a Ponzi gamble would succeed, the sequence $\left\{Q_{t}\right\}$ is bounded, where $Q_{t}=\Pi_{t=0}^{t}\left(R_{t} / G_{s}\right)$; $R_{1}$ is the gross return on government debt in period $s_{;} G_{2}$ is the gross growth rate of the wage; and period zero is the period when the young receive a transfer.

To prove the lemma, let $d$ be the ratio of the transfer in period zero to the wage in period zero. Since rolled-over debt grows at rate $R$, the ratio of debt to the wage under the gamble grows at rate $R / G$. Thus the ratio in period $t$ is $Q_{t} d$. If $\left\{Q_{t}\right\}$ is 
unbounded, then $\left\{Q_{l} d\right\}$ is unbounded. Hence, the ratio of debt to the wage exceeds any finite $\lambda$ in some period, contradicting the assumption that the Ponzi gamble succeeds.

We can now prove Proposition 1 by assuming that a Ponzi gamble succeeds and constructing an intervention that yields a Pareto improvement. This intervention consists of small reallocations of consumption across generations living at the same time; aggregate consumption in each period and the evolution of the capital stock are unaffected. The within-period reallocations are designed to resemble a pay-as-you-go social security system. In particular, in period zero the young reduce their consumption by a small fraction $\delta$ of their wage, and the old increase their consumption by the same amount. In the following periods, the young reduce their consumption by an amount that grows at rate $R$ and the old increase their consumption by the same amount. Since the transfer from young to old grows at rate $R$ and the wage grows at rate $G$, the transfer in period $t$ is a fraction $\delta Q_{t}$ of the wage at $t$. Since $\delta$ is small and $\left\{\ell_{t}\right\}$ is bounded, the transfer is a small fraction of the wage in every period. (If $\left\{Q_{l}\right\}$ were unbounded, the transfer from young to old would grow relative to the scale of the economy, making the intervention impossible.)

Clearly the intervention benefits the generation that is old in period zero, because their consumption when old is higher and their consumption when young is unchanged. To establish that the intervention is a Pareto improvement, we show that there is no effect on the objective function (1) for the generations that 
follow. A generation that is young in period $t \geq 0$ gives up $\delta Q_{t} W_{t}$ units of consumption when young and gains $\delta Q_{t+1} W_{t+1}$ when old, where $W_{l}$ is the wage in period $t$. Using the definition of $Q$, the gain when old can be rewritten as $\delta Q_{t} W_{t} R_{t+1}$. For a small $\delta$, the effect of the reallocation on utility is $-\delta Q_{t} W_{t} u^{\prime}\left(C_{t}^{y}\right)+\delta Q_{t} W_{t} R_{1+1} E_{t} v^{\prime}\left(C_{t+1}^{o}\right)=$ $\delta Q_{1} W_{t}\left[-u^{\prime}\left(C_{t}^{y}\right)+R_{t+1} E_{l} v^{\prime}\left(C_{t+1}^{o}\right)\right]$, where $u^{\prime}(\cdot)$ and $v^{\prime}(\cdot)$ are evaluated at the decentralized equilibrium. The term in brackets gives the marginal effect of forgoing a unit of consumption when young in exchange for safe debt, which yields $R_{t+1}$ units of consumption when old. This effect is zero by the assumption that individuals optimize in the initial equilibrium. Thus the intervention has no effect on the welfare of generations born at $t \geq 0$.

\section{The Infeasibility of Ponzi Schemes}

Proposition 1 has an immediate implication that makes clear why we focus on Ponzi gambles rather than Ponzi schemes:

Corollary: If the economy is dynamically efficient, then a Ponzi scheme is not feasible.

That is, in dynamically efficient economies, it is not possible for the government to carry out a pure debt rollover in all realizations of history. For some sequences of shocks, the stock of debt would become so large that it would exceed the demand for debt at any interest rate.

It is easy to establish this result given proposition 1. 
Suppose that a Ponzi scheme is feasible. Under the scheme, the ratio of the debt to the wage must lie below some finite bound $\lambda^{\prime}$ in all realizations of history. (Otherwise, the debt could exceed the wages of the young, making it impossible for the young to buy all the debt.) since $D / W<\lambda^{\prime}$ in all realizations of history, $a$ Ponzi gamble with $\lambda=\lambda^{\prime}$ would succeed in all realizations of history: the debt would never hit the bound that triggers a tax increase. And since a gamble succeeds with certainty, Proposition 1 implies that there is a government intervention that yields a Pareto improvement with certainty. The possibility of a certain Pareto improvement implies that the initial equilibrium is not dynamically efficient.

This corollary is of independent interest in the context of previous work on Ponzi schemes. It is well known that dynamic efficiency rules out Ponzi schemes in deterministic overlappinggenerations models. There are, however, few general results about the feasibility of Ponzi schemes under uncertainty. our result shows that the implications of dynamic efficiency generalize to the stochastic case.

At first, our corollary might seem inconsistent with some examples in Blanchard and Weil (1992) of "dynamically efficient" economies in which Ponzi schemes are possible. Recall, however, that Blanchard and Weil use a weaker definition of dynamic efficiency. It is only our more demanding definition of dynamic efficiency that rules out Ponzi schemes. As we noted earlier, actual economies appear to be dynamically efficient even according 
to this more demanding definition.

\section{Pareto-Improving Fiscal policy}

Proposition 1 establishes a connection between the success of a Ponzi gamble and the government's ability to improve on the decentralized equilibrium. However, the Pareto improvement that we construct involves commands to shift consumption between generations. The Proposition leaves open the question of whether the government can engineer a Pareto improvement through fiscal policy--by setting lump-sum taxes and transfers rather than directly reallocating consumption. Our second Proposition establishes that this is indeed possible for the realizations of history in which a Ponzi gamble succeeds:

Proposition 2: Starting from the decentralized equilibrium, there exists a series of taxes and transfers that raises utility for one generation and does not reduce utility for any generation in any realization of history in which a Ponzi gamble would succeed.

The Appendix proves Proposition 2 by constructing such a series of taxes and transfers. To interpret the proposition, note that the appropriate policy will generally not be a Ponzi gamble itself. Even if successful, a simple Ponzi gamble -- a transfer to one generation -- may not yield a Pareto improvement. Government borrowing reduces capital accumulation and thus can alter the paths 
of wages and interest rates in ways that hurt future generations, even if they do not pay taxes. If a Ponzi gamble would succeed, however, there is always a variation on such a policy that does yield a pareto improvement. In the policy constructed in the Appendix, the government issues transfers in one period and then runs a balanced primary budget, as in a Ponzi gamble. In the balanced-budget periods, however, the government uses taxes and transfers to reallocate resources across the two generations alive during the period. These budget-neutral transfers compensate each generation for the changes in factor prices caused by government debt. 5

\section{Welfare-Improving Crowding out}

From one point of view, it is not surprising that the government can raise welfare if a Ponzi gamble succeeds. It seems natural that welfare rises if one generation receives a transfer and no generation pays a tax. From a different point of view, however, our results may appear counterintuitive. As mentioned in the previous section, government deficits reduce investment even if they never lead to higher taxes, because savers substitute government bonds for capital. According to conventional wisdom,

${ }^{5}$ We conjecture that there are a variety of other policies that yield a Pareto improvement if a Ponzi gamble would succeed. In particular, we believe that the government could issue a series of transfers to the young, with no taxes on any generation.

once again, our points are analogous to previous results for dynamically inefficient deterministic economies. Fiscal policy can create a Pareto improvement in such economies, but the necessary intervention is more complicated than a transfer to one generation. 
such crowding-out inevitably reduces future consumption, hurting future generations, if the economy is dynamically efficient. Why does this argument not apply in our model?

We have shown that, if a Ponzi gamble succeeds, fiscal policy can raise welfare under quite general conditions, However, the mechanism through which this occurs is different in different economic environments. In this section, we illustrate the possible mechanisms with two examples. Since we wish to focus on dynamically efficient economies, we consider examples in which the AZ condition is satisfied: profits exceed investment in every period.

In our first example, there is a single kind of risky capital. A Ponzi gamble reduces investment, and this crowding-out reduces the expected level of consumption for some generations. But the Ponzi gamble also reduces the variance of consumption, because government debt is safer than the capital it replaces. Because of this decrease in risk, no generation is worse off as long as the gamble succeeds.

our second example assumes, more realistically, that there is more than one kind of capital. Capital goods differ in their riskiness. In this case, a Ponzi gamble reduces the total level of capital but also changes its composition: when savers buy government debt, they also shift toward capital with higher risk and return. Because of this portfolio adjustment, crowding-out does not affect either the mean or variance of consumption, and thus does not reduce welfare. 
Both of our examples are simple: we assume log utility, linear production functions, and two-point distributions for shocks. The purpose of these examples is to illustrate the kinds of mechanisms underlying the more general results of the previous section.

Example 1: A Single Capital Good

Assume that the lifetime-utility function (1) takes the form

$$
(1-\beta) \log \left(c_{t}^{y}\right)+\beta E_{t} \log \left(c_{t+1}^{0}\right),
$$

where $0<\beta<1$. This specification yields the familiar result that the young save a constant fraction $\beta$ of their wage. Let the percapita production function be

$$
f\left(k_{t}\right)=w_{t}+R_{t} k_{t}
$$

where $W_{1}$ and $R_{1}$ are exogenous and stochastic. Under competition, $W$ is the wage and $R$ is the gross return on capital.

Assume that there are two states of the world, Good and Bad, each of which occurs with probability one half every period. The return on capital $R_{1}$ equals $R_{G}$ in the good state and $R_{B}<R_{G}$ in the bad state. The growth rate of the wage, $W_{t} / W_{t-1}$, equals $G_{G}$ in the good state and $G_{B}<G_{O}$ in the bad state.

In this economy, it is easy to construct a fiscal policy that benefits all generations if a Ponzi gamble succeeds. The policy is simply the Ponzi gamble itself: the government issues transfers to one generation and never intervenes again (unless the gamble fails). In this example, there is no need for the more complicated fiscal interventions that are necessary in general, as described in 
the discussion of Proposition 2.6

To see that a successful Ponzi gamble is Pareto-improving, note first that the generation receiving the initial transfer benefits from the policy. And the generations that do not receive transfers cannot be worse off. To understand why, recall that the wage $W$ is exogenous; thus a Ponzi gamble has no effect on firstperiod consumption, $(1-\beta) W$, or savings, $\beta w$, for an individual who does not receive a transfer. The Ponzi gamble does affect the composition of savings: since the government issues debt and rolls it over, in equilibrium savers hold this debt and reduce their holdings of capital. However, this shift cannot make savers worse off, because they could still achieve the initial equilibrium. An individual could still choose to put his entire savings in the form of physical capital and earn the exogenous return $R_{1}$. since he chooses instead to hold debt, this must make him better off.

Recall that we are interested in economies that are dynamically efficient and have average growth rates above the interest rate on debt. Our current example can easily satisfy these conditions. To check dynamic efficiency, note that investment in period $t$ is $\beta W_{t}$ and profits are $R_{l} k_{l}=R_{l} \beta W_{t-1}$. $A$ sufficient condition for profits always to be larger, and thus for dynamic efficiency, is that the return on capital exceed the growth rate of wages: $R_{G}>G_{G}$ and $R_{B}>G_{B}$. To compare $G$ to the interest rate

${ }^{6}$ This result follows from the linearity of the production function, which implies that the crowding-out of capital does not affect factor prices. 
on debt, we derive this interest rate from an individual's firstorder condition for asset allocation. For small levels of debt, the interest rate is

$$
\text { (4) } \quad \bar{R}-\frac{R_{B} R_{G}}{E[R]} \text {, }
$$

where $E[R]=\left(R_{O}+R_{B}\right) / 2$. For sufficient dispersion between $R_{B}$ and $R_{G}$, this safe interest rate is less than $E[G]$ even though the return on capital exceeds $G$ in each state of nature.

But if the economy is dynamically efficient, why doesn't crowding out reduce welfare? since savers replace capital with debt, which has a lower average return, their expected consumption when old is lower. This reduction in average consumption is the analogue of the crowding-out effect in dynamically efficient, deterministic economies. Under uncertainty, however, crowding out has an additional effect: it reduces the variance of consumption when old, because debt is safer than capital. The benefit from less variable consumption must outweigh the loss from the lower mean, because savers choose to shift from capital to debt.

We should emphasize again that these results apply only to realizations of history in which a Ponzi gamble succeeds. When the government launches a gamble, there is a chance that it will fail, requiring future tax increases. Because of this risk, the gamble is undesirable ex ante for some generations. If the gamble succeeds, however, then it yields a Pareto improvement ex post. 


\section{Example \#2: Two Capital Goods}

We now modify our example by assuming that there are two kinds of physical capital. The aggregate production function is

$$
f\left(k_{1 t}, k_{2 t}\right)-w_{t}+R_{1 t} k_{1 t}+R_{2 t} k_{2 t}
$$

where $k_{1}$ and $k_{2}$ are the per-capita quantities of the two kinds of capital. Both $R_{1}$ and $R_{2}$ take on different values in the good and bad states of the world. We assume that $k_{2}$ has a higher average return than $k_{1}$ but is also riskier: it pays more than $k_{1}$ in the good state but less in the bad state. That is, we assume $E\left[R_{2}\right]>E\left[R_{1}\right]$ and $R_{2 O}>R_{10}>R_{1 B}>R_{2 B}$. We assume the four $R^{\prime} s$ are such that, in the equilibrium derived below, savers hold both kinds of capital if there is no government debt.

We first consider the behavior of the economy without debt. As in the previous example, an individual receives an exogenous wage $w$ and, with log utility, consumes $(1-\beta) w$ when young. The individual splits his savings of $\beta w$ between the two types of capital. He faces a tradeoff between risk and return, or equivalently between consumption in the two states of nature: by holding more of the safer asset $k_{1}$, he gives up consumption in the good state for more consumption in the bad state. Specifically, given total savings of $\beta \mathrm{W}$, the saver's constraint can be written

$$
c_{G}^{\circ}-\alpha+\gamma c_{B}^{0}
$$


where $c_{G}^{o}$ and $c_{B}^{o}$ are second-period consumption in the two states, $\alpha$ $=\beta \mathrm{W}\left(\mathrm{R}_{2 \mathrm{G}} \mathrm{R}_{1 \mathrm{~B}}-\mathrm{R}_{1 \mathrm{G}} \mathrm{R}_{2 \mathrm{~B}}\right) /\left(\mathrm{R}_{1 \mathrm{~B}}-\mathrm{R}_{2 \mathrm{~B}}\right)>0$, and $\gamma=\left(\mathrm{R}_{1 \mathrm{G}}-\mathrm{R}_{2 \mathrm{G}}\right) /\left(\mathrm{R}_{1 \mathrm{~B}}-\mathrm{R}_{2 \mathrm{~B}}\right)<-1$. Subject to this constraint, the saver chooses $c_{\mathrm{o}}^{\circ}$ and $\mathrm{C}_{\mathrm{B}}^{\circ}$ to maximize expected utility when old, $1 / 2\left[\log \left(C_{\mathrm{o}}^{\circ}\right)+\log \left(\mathrm{C}_{\mathrm{B}}^{\circ}\right)\right] .7$

We now derive the effects of a successful Ponzi gamble, focusing as in the previous example on generations that do not receive a transfer. Once again, the policy has no effect on these generations' first-period consumption $(1-\beta)$ w or their total savings $\beta \mathrm{w}$. The introduction of debt shifts savers' portfolios, but, perhaps surprisingly, there is no effect on the distribution of consumption when old. Thus there is no effect on expected utility when old.

To establish this point, we first derive the equilibrium interest rate on debt. When a saver substitutes debt for either kind of capital, he reduces both his risk and his average return, just as when he substitutes $k_{1}$ for $k_{2}$. That is, adding debt to his portfolio raises consumption in the bad state at the expense of consumption in the good state. The required return on debt is defined by the condition that the tradeoff between consumption in the two states be the same when debt is substituted for capital as when $k_{1}$ is substituted for $k_{2}$ i if the return were lower, buying debt would be an inefficient way to reduce risk. When $k_{1}$ is substituted

\footnotetext{
${ }^{7}$ The saver also faces the constraints that $c_{B}^{\circ}$ cannot exceed $\beta \mathrm{WR}_{1 \mathrm{~B}}$, its level when he holds only $k_{1}$, and that $c_{\mathrm{g}}^{\mathrm{o}}$ cannot exceed $\beta \mathrm{WR}_{2 \mathrm{G}}$, its level when he holds only $\mathrm{k}_{2}$. Since we assume that the saver holds both kinds of capital, these constraints are not binding.
} 
for $k_{2}$, the cost in $c_{a}^{0}$ per unit of $c_{B}^{0}$ is $-\gamma=\left(R_{2 G}-R_{1 G}\right) /\left(R_{1 B}-R_{2 B}\right)$. similarly, when debt is substituted for $k_{1}$, the cost is $\left(R_{10}-\bar{R}\right) /(\bar{R}-$ $R_{1 B}$ ). Equating these two expressions yields the solution for $\bar{R}$ :

$$
\bar{R}-\frac{R_{1 B} R_{2 G}-R_{1 G} R_{2 B}}{R_{2 G}-R_{1 G}+R_{1 B}-R_{2 B}}
$$

We can now see why the introduction of debt does not affect the distribution of consumption: debt is a redundant asset. By substituting debt for capital, a saver can substitute bad-state consumption for good-state consumption, but he could already do so by shifting between types of capital. And, in equilibrium, the tradeoff rate is the same $(-\gamma)$ in either case. Thus the introduction of debt does not alter the constraint (6) that the saver faces. Since a saver maximizes the same objective function subject to the same constraint, his choices of $c_{G}^{0}$ and $c_{B}^{0}$ are the same. Debt does not affect either the mean or variance of secondperiod consumption, and therefore does not affect utility for generations that do not receive transfers. This establishes that a successful Ponzi gamble yields a Pareto improvement.

How can crowding-out of capital by debt have no effect on consumption? The answer is that the introduction of debt alters the composition of the capital stock as well as reducing its total size. When savers acquire safe debt, they adjust their portfolios by substituting toward riskier forms of capital, leaving their overall levels of risk and return unchanged. This shift toward riskier capital is similar to the "crowding-in" effect described by 
Friedman (1978): an increase in debt leads to increased holdings of assets that are poor substitutes for debt, in this case high-risk capital. This mechanism is absent from the previous example, in which debt reduces both the mean and variance of consumption.

\section{v. Conclusion}

According to a popular metaphor, government budget deficits are like termites eating away at your house. Over any short period of time, the effects are quite minor, and there is little harm to putting off the solution for a bit longer. But, if the problem is left untreated for a long period, the adverse effects are substantial and inevitable.

our analysis in this paper suggests that a different metaphor is more appropriate. Government budget deficits are more like a homeowner's decision not to buy fire insurance. The policy is not advisable, because the adverse effects can be large, but these adverse effects occur with a low probability. Indeed, the result of the policy will be a higher living standard as long as the unlikely adverse outcomes do not happen to occur.

our conclusion is based on the observation that the return on government debt is usually less than the growth rate of the economy. Therefore, the government can most likely run a successful Ponzi gamble by deficit spending for a while without ever raising taxes to repay the debt and accumulated interest. It would be wrong to conclude that such a Ponzi gamble is desirable ex 
ante, for it is not certain to succeed. Yet it does succeed with a high probability. And when it succeeds, it can raise welfare for all generations.

This alternative view of government debt has important implications for policy evaluation. For example, in the 1994 Economic Report of the President, the Council of Economic Advisers uses a textbook solow model to estimate the effects of deficit reduction on economic growth (pp. 85-87). Romer (1988) presents more sophisticated calculations but, like the Economic Report, works exclusively in models with certainty. The analysis of this paper suggests that such exercises are incomplete at best. Estimating the effects of deficit reduction requires explicit modelling of the uncertainty concerning future economic growth and interest rates.

our alternative view of government debt may also help explain why Ronald Reagan chose to preside over the profligate fiscal policy of the 1980s. Biographers of Ronald Reagan often note his boundless optimism. This optimism was in part due to his own unlikely rise from an actor in B movies to President of the United States. Perhaps Reagan's optimism manifested itself in excessive confidence about future economic growth, and this confidence made him less concerned about increasing the level of government debt. This hypothesis is consistent with the account of events offered by Martin Feldstein, chairman of the Council of Economic Advisers from 1982 to 1984 . Feldstein (1994, p. 59) reports that he warned Reagan of the dangers of the deficit, but that the President 
"continued to hope that higher growth would come to his rescue." Put simply, an eternal optimist like Ronald Reagan may choose to accept a gamble that a realist would deem imprudent. 


\section{Appendix 1: The Data}

The growth rate of income (g) equals the growth rate of nominal GNP from Romer (1989) for 1870 to 1928 and from the National Income and Product Accounts for 1929 to 1992.

The yield on U.S. government bonds with one year to maturity $\left(\mathrm{r}^{A}\right)$ equals the nominal interest rate from Cecchetti et al (1990) for 1871 to 1987 and the ask yield on Treasury bills with almost a year to maturity for 1988 to 1992 .

The average yield on government debt $\left(r^{\mathrm{B}}\right)$ equals interest payments in a year divided by the par value of outstanding debt at the beginning of the year. Interest on the public debt from U.S. Bureau of the census (1975, series Y461) for 1871 to 1940 is spliced multiplicatively to net interest on the federal debt less other interest from $C B O$ (1993, table A-1) for 1940 to 1992. Par value of the debt from Census (1975, series Y493) for 1870 to 1940 is spliced multiplicatively to debt held by the public from $C B O$ (1993, table A-2) for 1940 to 1992 . We convert fiscal year data to calendar year form.

The average return on government debt $\left(r^{\mathrm{C}}\right)$ is the sum of interest payments and the revaluation of outstanding debt during a year, divided by the market value of debt at the beginning of the year. The market value of debt equals the par value multiplied by a conversion factor; this conversion factor is RATIO2 from seater (1981, table 4) for 1919 to 1975 and is constructed using the formula in Butkiewicz (1983) for 1976 to 1992 . The revaluation of debt equals the change in the market value of outstanding debt less 
the budget deficit. The budget deficit from Census (1975, series Y337) for 1919 to 1928 is spliced multiplicatively to Census (1975, series Y341) for 1929 to 1961 and CBO (1994, table E-2) for 1962 to 1992. Again, we convert fiscal year data to calendar year form. The debt-income ratios for OECD countries besides the United States come from OECD (1994) and are estimates for 1994 of net government debt divided by GDP. 
Appendix 2: Proof of Proposition 2

Assume the success of a Ponzi gamble that begins with a transfer to the young in period zero equal to a small fraction $\delta$ of their wage. We construct a feasible sequence of taxes and transfers that yields a Pareto improvement.

We define the sequence of policies iteratively. In period zero, the young receive a small fraction $\delta$ of their wage, as in a Ponzi gamble. In any period t>0, the policy depends on the capital stock $k_{t}$, which equals savings at $t-1$. Let $\Delta_{t}$ equal the effect on $k_{t}$ of the sequence of policies: the value of $k_{t}$ under the intervention minus the value in the initial equilibrium. In all periods $t>0$, the young receive a transfer equal to $\Delta_{l} k_{t}\left(\partial^{2} f / \partial k_{t}^{2}\right)$, where $k_{t}$ is evaluated at the initial equilibrium. In all periods $t>0$, the old pay the same amount in taxes.

Under this sequence of policies, net transfers are zero after period zero. Consequently, the path of government debt is the same as in a Ponzi gamble in which the government intervenes only in period zero. Thus the fiscal policy we consider is feasible if a Ponzi gamble succeeds.

It remains to show that the policy yields a Pareto improvement. We first show that individuals born in any period $t>0$ are indifferent to the policy. An individual's utility, expression (1), is determined by the wage, interest rates, and transfers he faces and by his choice of savings when young. We denote savings by an individual born at $t$, which equals his holdings of capital at $t+1$, by $k_{i t+1}$. In equilibrium, $k_{i t+1}$ equals $k_{t+1}$, the per-capita 
capital stock at $t+1$. But, by the envelope theorem, we can hold constant the individual's savings when calculating the effect of a small fiscal intervention on utility.

If $k_{i t+1}$ is held constant, it is straightforward to show that an individual born at $t>0$ is indifferent to our policy, because it does not affect his consumption in either period of life. When the individual is young, he receives a wage of $f\left(k_{t}, \theta_{t}\right)-k_{t}\left(\partial f / \partial k_{t}\right)$. The effect of the intervention on the wage is $\Delta_{1}$, the change in the capital stock, times $\partial w_{t} / \partial k_{t}$. This equals $-\Delta_{\mathrm{l}} k_{\mathrm{t}}\left(\partial^{2} f / \partial k_{\mathrm{l}}{ }^{2}\right)$. Since the individual receives a transfer of $\Delta_{t} k_{t}\left(\partial^{2} f / \partial k_{t}^{2}\right)$, his total income when young is unaffected by the policy. If we hold constant the individual's savings, his consumption when young is also unaffected.

When old, the individual receives interest income of $\mathrm{k}_{\mathrm{it}+1}\left(\partial \mathrm{f} / \partial \mathrm{k}_{\mathrm{t}+1}\right)$. The fiscal intervention raises this income by $\Delta_{t+1} k_{i t+1}\left(\partial^{2} f / \partial k_{t+1}{ }^{2}\right)$, which equals $\Delta_{t+1} k_{t+1}\left(\partial^{2} f / \partial k_{t+1}{ }^{2}\right)$ at the initial equilibrium. since an old individual pays a tax of this amount, his total income is unaffected by the intervention. since consumption equals income for an old individual, his consumption is unaffected. This result holds for any realization of the state of nature in period $t+1$.

We have established that generations born after period zero are indifferent to our policy. To establish that the policy is Pareto-improving, it remains to show that it benefits an individual born in period zero. Holding constant the individual's savings, the intervention raises his consumption when young, because his 
wage is unaffected and he receives a positive transfer. By reasoning similar to the above, the intervention has no effect on the individual's consumption when old. Since the policy increases consumption when young, it increases the individual's utility. 


\section{REFERENCES}

Abel, Andrew B., N. Gregory Mankiw, Lawrence H. Summers, and Richard J. Zeckhauser, "Assessing Dynamic Efficiency: Theory and Evidence," Review of Economic Studies 56 (January 1989), $1-20$

Blanchard, Olivier Jean, and Phillipe Weil, "Dynamic Efficiency, the Riskless Rate, and Debt Ponzi Games under Uncertainty," NBER Working Paper \#3992, February 1992.

Bohn, Henning, "The Sustainability of Budget Deficits with Lump-Sum and with Income-Based Taxation," Journal of Money, Credit, and Banking 23 (August 1991, Part 2), 580-604.

Bohn, Henning, "Fiscal Policy and the Mehra-Prescott Puzzle: On the Welfare Implications of Budget Deficits when Real Interest Rates are Low," Department of Economics, University of California at Santa Barbara, Working Paper No. 8-93, 1993. Butkiewicz, James L., "The Market Value of outstanding Government Debt: Comment," Journal of Monetary Economics 11 (May 1983), $373-79$.

Cass, David, "On Capital Overaccumulation in the Aggregative Neoclassical Model of Economic Growth: A Complete Characterization," Journal of Economic Theory 4 (1972), $200-23$

Cecchetti, stephen G., Pok-Sang Lam, and Nelson C. Mark, "Mean Reversion in Equilibrium Asset Prices," American Economic Review 80 (June 1990), 398-418. 
Congressional Budget office, Federal Debt and Interest Costs, CBO Study, May 1993.

Congressional Budget office, The Economic and Budget outlook: Fiscal Years 1995-1999, CBO Study, January 1994.

Council of Economic Advisers, Economic Report of the President, 1994 .

Diamond, Peter, "National Debt in a Neoclassical Growth Model," American Economic Review 55 (December 1965), 1126-50.

Feldstein, Martin, "American Economic Policy in the 1980s: A Personal View," in Martin Feldstein (ed.), American Economic Policy in the 1980s, University of Chicago Press, 1994.

Friedman, Benjamin M., "Crowding Out or crowding In? Economic Consequences of Financing Government Deficits," Brookings Papers on Economic Activity, 1978:3, 593-641.

O'Connell, Stephen A., and Stephen P. Zeldes, "Rational Ponzi Games," International Economic Review 29 (August 1988), 43150 .

Organization of Economic Cooperation and Development, OECD Economic Outlook, June 1994 .

Peled, Dan, "Informational Diversity over Time and the Optimality of Monetary Equilibria," Journal of Economic Theory 28 (December 1982), 255-74.

Romer, Christina D., "The Prewar Business Cycle Reconsidered: New Estimates of Gross National Product, 1869-1928," Journal of Political Economy 97 (February 1989), 1-37.

Romer, David, "What are the Costs of Excessive Deficits?," NBER 
Macroeconomics Annual $1988,63-98$.

Seater, John J., "The Market Value of Outstanding Government Debt, 1919-1975," Journal of Monetary Economics 8 (July 1981), 85101.

U.S. Bureau of the Census, Historical Statistics of the United states, Colonial Times to 1970 , Part 2, 1975. 
Table 1

SUMMARY STATISTICS

\begin{tabular}{|c|c|c|c|c|c|c|}
\hline \multirow{2}{*}{ Variable } & \multirow{2}{*}{ Sample } & \multirow{2}{*}{ Mean } & \multirow{2}{*}{$\begin{array}{l}\text { Standard } \\
\text { Deviation }\end{array}$} & \multicolumn{3}{|c|}{ Fraction of periods $>1$} \\
\hline & & & & $1 \mathrm{yr}$ & $5 \mathrm{yr}$ & $10 \mathrm{yr}$ \\
\hline g & $1871-1992$ & .059 & .08 & & & \\
\hline g & $1920-1992$ & .065 & .08 & & & \\
\hline g & 1946-1992 & .074 & .04 & & & \\
\hline$r^{A}$ & $1871-1992$ & .043 & .02 & & & \\
\hline $\mathbf{r}^{\mathrm{A}}$ & $1920-1992$ & .042 & .03 & & & \\
\hline$r^{A}$ & $1946-1992$ & .053 & .03 & & & \\
\hline$\left(1+r^{A}\right) /(1+g)$ & $1871-1992$ & .989 & .08 & .41 & .36 & .36 \\
\hline$\left(1+r^{A}\right) /(1+g)$ & $1920-1992$ & .985 & .09 & .34 & .30 & .27 \\
\hline$\left(1+r^{A}\right) /(1+g)$ & $1946-1992$ & .981 & .04 & .32 & .23 & .15 \\
\hline $\mathrm{r}^{\mathrm{B}}$ & 1871-1992 & .040 & .03 & & & \\
\hline$r^{B}$ & $1920-1992$ & .048 & .03 & & & \\
\hline $\mathrm{r}^{\mathrm{B}}$ & 1946-1992 & .058 & .03 & & & \\
\hline$\left(1+r^{B}\right) /(1+g)$ & $1871-1992$ & .986 & .08 & .41 & .33 & .32 \\
\hline$\left(1+r^{B}\right) /(1+g)$ & 1920-1992 & .990 & .09 & .40 & .32 & .29 \\
\hline$\left(1+r^{B}\right) /(1+g)$ & 1946-1992 & .986 & .04 & .38 & .23 & .17 \\
\hline $\mathrm{r}^{\mathrm{c}}$ & $1920-1992$ & .053 & .06 & & & \\
\hline $\mathrm{r}^{\mathrm{c}}$ & $1946-1992$ & .057 & .05 & & & \\
\hline$\left(1+r^{9}\right) /(1+g)$ & $1920-1992$ & .995 & .10 & .37 & .35 & .28 \\
\hline$\left(1+r^{c}\right) /(1+g)$ & $1946-1992$ & .984 & .06 & .28 & .23 & .17 \\
\hline Note: & les are de & the tex & & & & \\
\hline
\end{tabular}


Table 2

ESTIMATES OF AUTOREGRESSIVE PROCESSES

\begin{tabular}{|c|c|c|c|c|}
\hline Dependent Variable & Sample & $\begin{array}{c}\text { Adjusted } \\
\qquad \mathbf{R}^{2}\end{array}$ & $\begin{array}{c}\text { AR(1) } \\
\text { Coefficient }\end{array}$ & $\begin{array}{l}\mathrm{p} \text {-value } \\
\text { for } Q(5)\end{array}$ \\
\hline $\log \left(\left(1+r^{\wedge}\right) /(1+g)\right)$ & $1871-1992$ & .22 & $.47^{*}$ & .24 \\
\hline $\log \left(\left(1+r^{\wedge}\right) /(1+g)\right)$ & $1920-1992$ & .35 & $.59^{*}$ & .19 \\
\hline $\log \left(\left(1+r^{\wedge}\right) /(1+g)\right)$ & 1946-1992 & .12 & $.37^{*}$ & .64 \\
\hline $\log \left(\left(1+r^{B}\right) /(1+g)\right)$ & $1871-1992$ & .21 & $.46^{*}$ & .30 \\
\hline $\log \left(\left(1+r^{B}\right) /(1+g)\right)$ & $1920-1992$ & .35 & $.59^{*}$ & .12 \\
\hline $\log \left(\left(1+r^{B}\right) /(1+g)\right)$ & $1946-1992$ & .23 & $.49^{*}$ & .37 \\
\hline $\log \left(\left(1+r^{9}\right) /(1+g)\right)$ & $1920-1992$ & .06 & $.27^{*}$ & .42 \\
\hline $\log \left(\left(1+r^{c}\right) /(1+g)\right)$ & $1946-1992$ & .02 & .21 & .44 \\
\hline $\begin{array}{l}\text { Variable } \\
\text { level. } \\
\text { serial co }\end{array}$ & \multicolumn{4}{|c|}{$\begin{array}{l}\text { Variables are defined in the text. " denotes significance at the } 5 \% \\
\text { level. Q statistics correspond to Box-Ljung tests for the absence of } \\
\text { serial correlation through the } 5 \text { th lag. }\end{array}$} \\
\hline
\end{tabular}


Table 3

PROBABILITIES OF THE PONZI GAMBLE FAILING

\begin{tabular}{|c|c|c|c|c|c|c|}
\hline \multirow{2}{*}{$\begin{array}{l}\text { Interest } \\
\text { Rate }\end{array}$} & \multirow{2}{*}{ Sample } & \multicolumn{5}{|c|}{ Probability of the Ponzi Gamble Failing in: } \\
\hline & & 25 yrs & 50 yrs & $100 \mathrm{yrs}$ & $500 \mathrm{yrs}$ & 1000 yrs \\
\hline & & \multicolumn{5}{|c|}{-- critical value of debt-income ratio $=1.0$} \\
\hline $\mathbf{r}^{\wedge}$ & $1871-1992$ & .08 & .13 & .17 & .20 & .20 \\
\hline$r^{\wedge}$ & $1920-1992$ & .10 & .16 & .21 & .24 & .24 \\
\hline$r^{\wedge}$ & $1946-1992$ & .00 & .00 & .00 & .00 & .00 \\
\hline$r^{B}$ & $1871-1992$ & .08 & .13 & .16 & .18 & .18 \\
\hline$r^{B}$ & $1920-1992$ & .15 & .24 & .31 & .39 & .40 \\
\hline$r^{B}$ & 1946-1992 & .00 & .00 & .01 & .01 & .01 \\
\hline $\mathrm{r}^{\mathrm{c}}$ & $1920-1992$ & .07 & .12 & .16 & .20 & .20 \\
\hline \multirow[t]{2}{*}{$r^{c}$} & 1946-1992 & .01 & .01 & .02 & .02 & .02 \\
\hline & & \multicolumn{5}{|c|}{--- critical value of debt-income ratio $=1.5$} \\
\hline$r^{\wedge}$ & $1871-1992$ & .02 & .05 & .08 & .11 & .11 \\
\hline$r^{\wedge}$ & $1920-1992$ & .03 & .07 & .11 & .14 & .14 \\
\hline$r^{\wedge}$ & 1946-1992 & .00 & .00 & .00 & .00 & .00 \\
\hline $\mathbf{r}^{\mathrm{B}}$ & $1871-1992$ & .01 & .03 & .05 & .06 & .06 \\
\hline$r^{B}$ & 1920-1992 & .05 & .11 & .19 & .27 & .28 \\
\hline $\mathrm{r}^{\mathrm{B}}$ & $1946-1992$ & .00 & .00 & .00 & .00 & .00 \\
\hline $\mathrm{r}^{\mathrm{c}}$ & $1920-1992$ & .01 & .03 & .06 & .09 & .09 \\
\hline $\mathrm{r}^{\mathrm{c}}$ & $1946-1992$ & .00 & .00 & .00 & .00 & .00 \\
\hline
\end{tabular}

Notes: Variables are defined in the text. Estimates are based on AR(1) specifications from Table 2 with bootstrapped errors. The primary deficit is set equal to zero in all years. 